\title{
Immunohistochemical localisation of factor VIII-related antigen in Hodgkin's disease
}

\author{
J CROCKER, PJ SMITH
}

From the Histopathology Department, East Birmingham Hospital, Bordesley Green East, Birmingham, B95ST

SUMMARY A series of 45 lymph nodes involved by Hodgkin's disease have been examined by means of the unlabelled antibody peroxidase-antiperoxidase (PAP) method for the demonstration

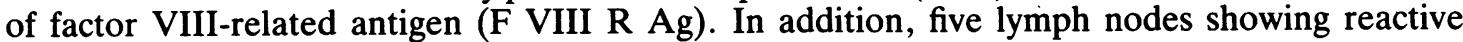
follicular hyperplasia were studied. In the specimens of nodular sclerosing Hodgkin's disease, many blood vessels were present, as demonstrated by virtue of F VIII R Ag in endothelial cells. These vessels were present within and, especially, around the nodules in this subtype; in addition the fibrous trabeculae were densely vascular. High vascularity was also a feature of specimens of the cellular variant of nodular sclerosing Hodgkin's disease. However, the other three Rye subtypes of the disease showed a striking paucity of F VIII R Ag-positive blood vessels. The reactive nodes showed numerous vessels around and between follicles but the lymph sinuses were consistently negative. Mast cells were present in all specimens but were especially frequent within and adjacent to the sinuses in reactive specimens; they were strongly positive for the F VIII R Ag, their staining being abolished by pre-adsorption of the primary antiserum with factor VIII itself.

Factor VIII-related antigen (F VIII R Ag) has been shown to be synthesised by endothelial cells. ${ }^{1-5}$ The glycoprotein complex has subsequently been localised in endothelial cells by means of immunoperoxidase techniques. ${ }^{6-8}$ Most recently immunoelectron microscopy has been used to demonstrate F VIII R Ag ultrastructurally in endothelial cells, where activity was noted in the cisternae of the Golgi complex, confirming synthesis of this material by these cells. ${ }^{9}$

In the present study, use has been made of the unlabelled antibody peroxidase-antiperoxidase (PAP) technique to show F VIII R Ag in a series of specimens of Hodgkin's disease and reactive follicular hyperplasia. Previous studies of vascular structures in Hodgkin's disease by means of conventional histology ${ }^{10}$ and by the use of enzyme histochemical methods for alkaline phosphatase ${ }^{11} 12$ have revealed rather unusual structures in Hodgkin's disease. The blood vascular architecture has now been investigated by virtue of F VIII R Ag activity in endothelial cells.

Accepted for publication 26 September 1983

\section{Material and methods}

\section{TISSUES EXAMINED}

Forty-five specimens of Hodgkin's disease were examined, from the same number of patients. Of these, 15 were of the lymphocyte predominant Rye subtype, nine showed nodular sclerosis, 14 were of the mixed cellularity variety whilst the remaining seven specimens showed lymphocyte depletion. In addition, five cervical lymph nodes with reactive follicular hyperplasia were studied (Table).

TISSUE FIXATION, PROCESSING AND STAINING

Slices of the specimens were fixed for $24-48 \mathrm{~h}$ in $10 \%$ formol-saline solution at room temperature, then

Specimens of Hodgkin's disease and reactive follicular hyperplasia

\begin{tabular}{|c|c|c|}
\hline Rye subtypeldiagnosis & $\begin{array}{l}\text { Age range } \\
(y r)\end{array}$ & No of cases \\
\hline $\begin{array}{l}\text { Lymphocyte predominant } \\
\text { Nodular sclerosis } \\
\text { Mixed cellularity } \\
\text { Lymphocyte depleted } \\
\text { Reactive follicular hyperplasia }\end{array}$ & $\begin{array}{r}15-64 \\
15-68 \\
15-84 \\
18-70 \\
4-68\end{array}$ & $\begin{array}{l}15 \\
9 \text { ( } 3 \text { cellular variant }) \\
14 \\
7 \\
5\end{array}$ \\
\hline
\end{tabular}




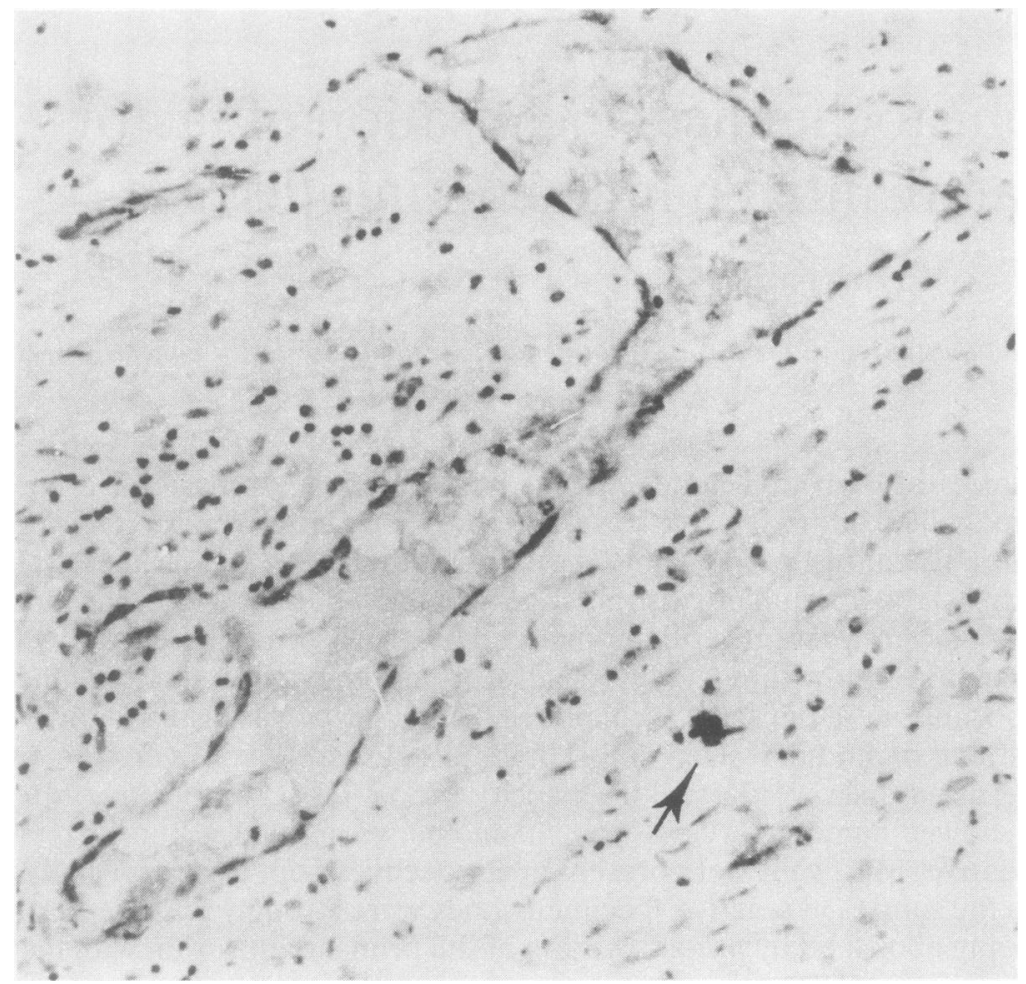

Fig. 1 Large venous channel in fibrotic area in a case of nodular sclerosing Hodgkin's disease, lined by F VIII R Ag-positive endothelial cells. A small cluster of positive mast cells is marked by an arrow. PAP method for F VIII $R$ Ag; haemalum counterstain $\times 180$.

routinely processed to paraffin wax. Sections were cut at $3 \mu \mathrm{m}$, then subsequently taken to water and placed in Tris-saline buffer ( $\mathrm{pH} 7 \cdot 6$ ) containing $0.1 \%$ trypsin and $0.1 \%$ calcium chloride for $30 \mathrm{~min}$ at room temperature, to increase the staining response to the PAP method. ${ }^{13}$ The sections were then treated with $0.1 \%$ hydrochloric acid in methanol for $30 \mathrm{~min}$ at room temperature to block endogenous peroxidase, followed by several washes in Tris-saline buffer, $\mathrm{pH}$ 7.6. A standard PAP reaction was then applied, using rabbit antihuman F VIII R Ag (Mercia Brocades Ltd, Weybridge, Surrey, UK) at a dilution of $1 / 50$ for the first stage, followed by swine antirabbit immunoglobulin serum, then rabbit PAP complex which was developed by the usual 3,3'-diaminobenzidine (DAB) procedure. Sections were counterstained with Mayer's haemalum, dehydrated, cleared and mounted in synthetic medium. The usual controls were exercised in the immunostaining procedure, namely: the optimum titre in the first antiserum stage, substitution for the first antiserum by normal rabbit serum and omission of each one of the antisera in the sequence. The reaction was "blocked" by factor VIII (Armour Pharmaceutical Co Ltd, Eastbourne, East Sussex, UK).

\section{Results}

STAINING FOR F VIII R AG IN GENERAL A moderate to strong staining response was obtained in the cytoplasm of endothelial cells in all specimens. Especially pronounced reactions were evident in capillaries and high endothelial vessels. Larger arteries and veins were lined by endothelial cells showing less intense (but definitely positive) staining (Figs. 1 and 2). Specific activity patterns in Hodgkin's disease and reactive follicular hyperplasia are discussed below.

In addition to endothelial cells, a further cell type was consistently demonstrated by virtue of F VIII $R$ $\mathrm{Ag}$, namely, the tissue mast cell. Mast cells were present in variable numbers in all specimens and showed moderate to strong staining activity (Fig. 3). They were readily identified by means of their coarse 


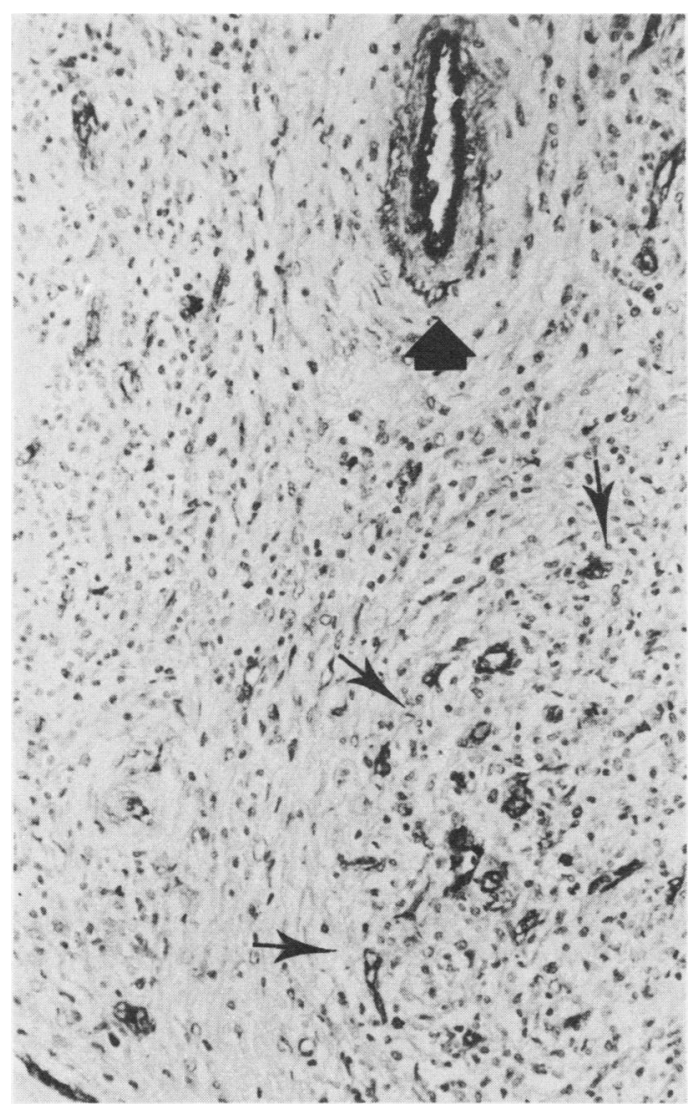

Fig. 2 Specimen of nodular sclerosing Hodgkin's disease showing an artery (large arrow) lined by $F$ VIII $R$ Ag-positive endothelial cells. A cellular nodule, the edge of which is indicated by small arrows, contains many vascular structures lined by F.VIII R Ag-positive endothelial cells. $P A P$ method for F VIII R Ag; haemalum counterstain $\times 120$.

cytoplasmic granularity and single rounded nucleus. All staining was abolished by pre-adsorption of the antiserum to F VIII $\mathrm{R} \mathrm{Ag}$ with the antigen.

\section{REACTIVE LYMPH NODES}

The same staining pattern was observed in all five specimens of reactive follicular hyperplasia. Small numbers of mast cells, staining positively for F VIII R $\mathrm{Ag}$, were scattered throughout all regions of the nodes but were especially frequent in the marginal, intermediate and medullary sinuses (Fig. 3) and in the regions adjacent to them. The sinus-lining cells, both of the "littoral" and "reticular" types, were uniformly negative.

Very occasional mature (Marschalko) plasma cells showed weak cytoplasmic activity but the large majority were entirely negative.

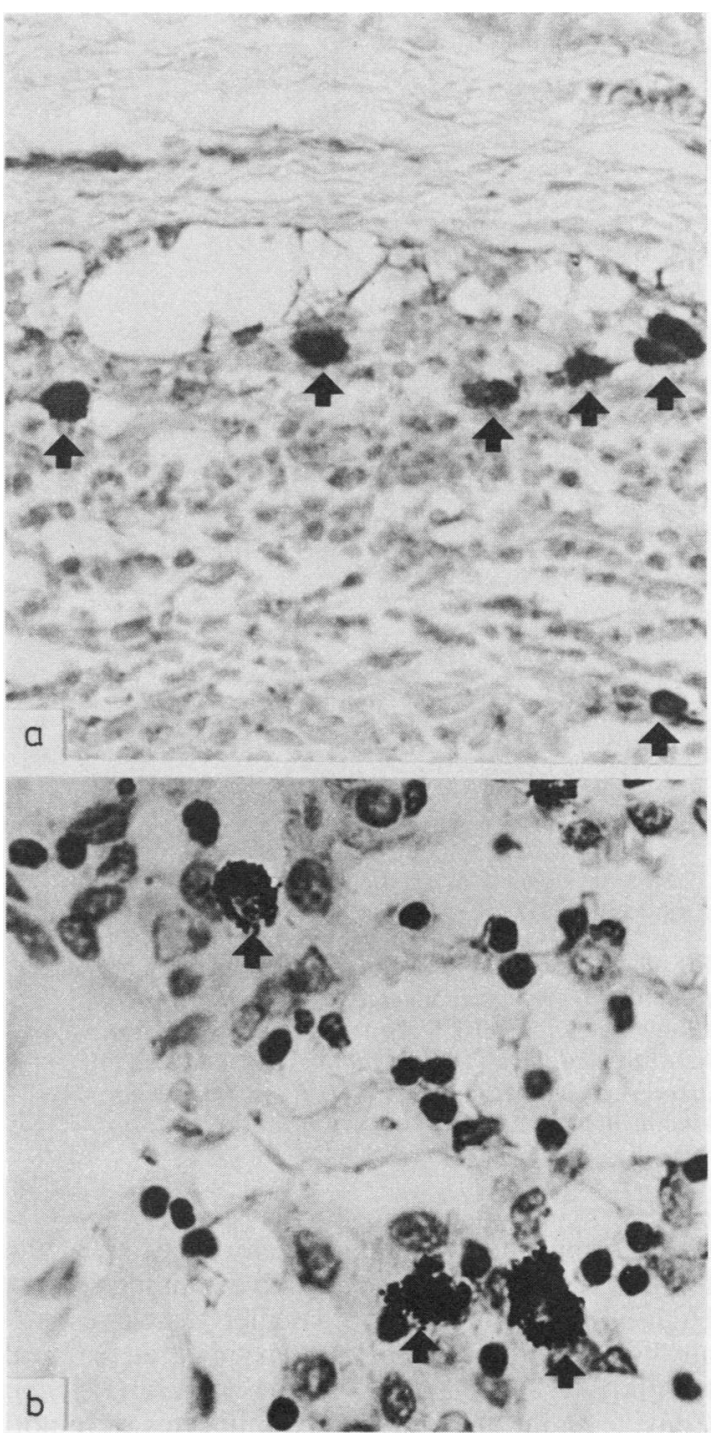

Fig. 3 (a) Marginal sinus of reactive lymph node. The sinus-lining cells are negative but several mast cells present adjacent to the sinuses are strongly positive (arrows). PAP method for F VIII R Ag; haemalum counterstain $\times 350$ (b) intermediate sinus of reactive lymph node containing three strongly FVIII R Ag-positive mast cells (arrows). PAP method for F VIII R Ag; haemalum counterstain $\times 400$.

A most striking pattern of vascular staining was seen in the interfollicular areas, vessels of all sizes being lined by endothelial cells of varying degrees of positivity for F VIII R Ag (Fig. 4). These positive blood vessels extended mainly into the paracortical and medullary areas, only a few small tributaries 


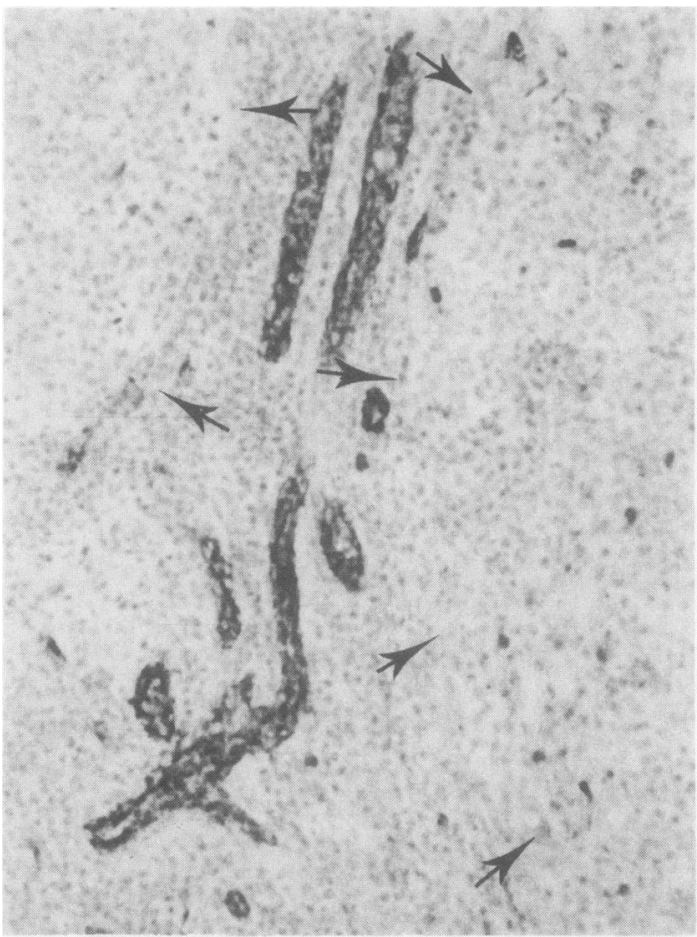

Fig. 4 Area between two follicles in a specimen of reactive follicular hyperplasia. Several large vascular structures showing strong FVIII R Ag activity are present around and between the follicles (whose outlines are indicated by arrows). PAP method for FVIII R Ag; haemalum counterstain $\times 180$.

encroaching upon the follicle centres. Most of the follicles were "outlined" by positive-staining vessels. High-power examination of smaller vessels, especially high endothelial vessels, often appeared to reveal lymphocytes in passage via their walls (Fig. 5). Convincing intracytoplasmic lymphocytes were not, however, observed.

Lymphocytes, centrocytes, centroblasts and macrophages were all negative and there was no suggestion of F VIII $\mathrm{R} \mathrm{Ag}$ activity on dendritic reticulum cells or within fibroblasts.

\section{HODGKIN'S DISEASE SPECIMENS}

Blood vessels of all sizes were observed in all specimens, regardless of Rye subtype, by virtue of their lining of endothelial cells, positive for F VIII R Ag. However, striking differences were noted in the numbers and complexity of small vessels, including, especially, capillaries and high endothelial vessels, in the different varieties of Hodgkin's disease. In lymphocyte predominant, mixed cellularity and

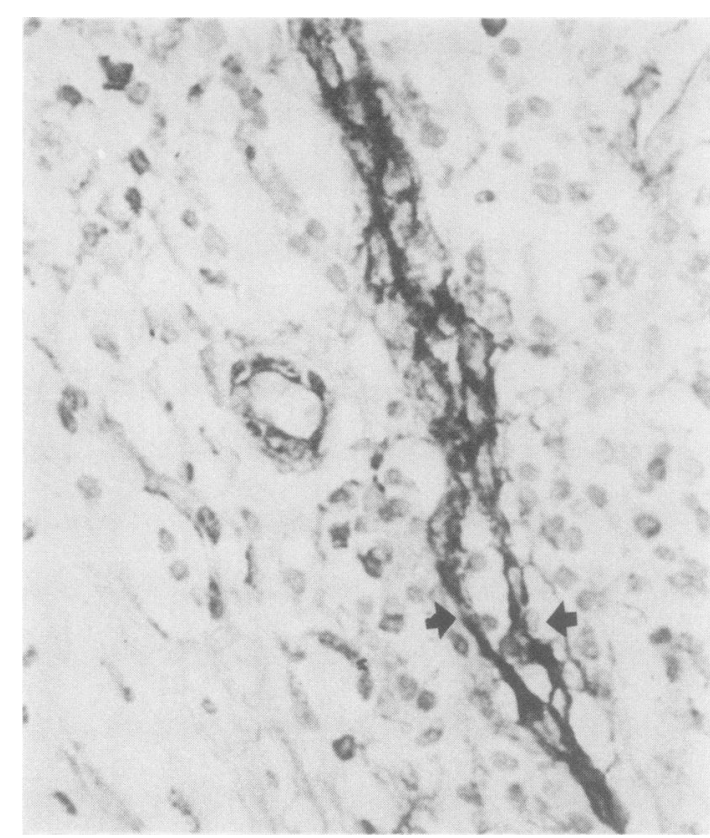

Fig. 5 Blood vessel, probably a high endothelial vessel, in interfollicular area of a specimen of reactive follicular hyperplasia. There is a suggestion of lymphocytic passage via the vessel wall (arrows). PAP method for F VIII R Ag; haemalum counterstain $\times 300$.

lymphocyte depleted subtypes, vessels lined by F VIII R Ag-positive endothelial cells were quite scant (Fig. 6) and when present were often palestaining, although larger vessels showing endothelial activity were present in the capsule. In contrast, all specimens of nodular sclerosing Hodgkin's disease revealed innumerable small vessels, including high endothelial vessels, in all areas, but most noticeably within fibrosis (Fig. 7). The endothelial cells in such vessels were strongly stained by F VIII $\mathrm{R} \mathrm{Ag}$ and were frequently situated in "leashes" around and between the cellular nodules in this subtype of Hodgkin's disease (Fig. 8) and within their periphery. Large numbers of such vessels were observed, even in the densely sclerotic collagen around the periphery of nodular sclerotic lymph nodes. Interestingly, in the three specimens of the cellular variant of nodular sclerosis, this high vascularity was present, even in the absence of dense fibrosis (Fig. 9).

Considerable numbers of F VIII $\mathrm{R}$ Ag-positive mast cells were present in all specimens. ReedSternberg and "Hodgkin cells" were negative, as were lymphocytes, neutrophil and eosinophil polymorphs and macrophages. As in reactive follicular hyperplasia, occasional plasma cells stained weakly. 


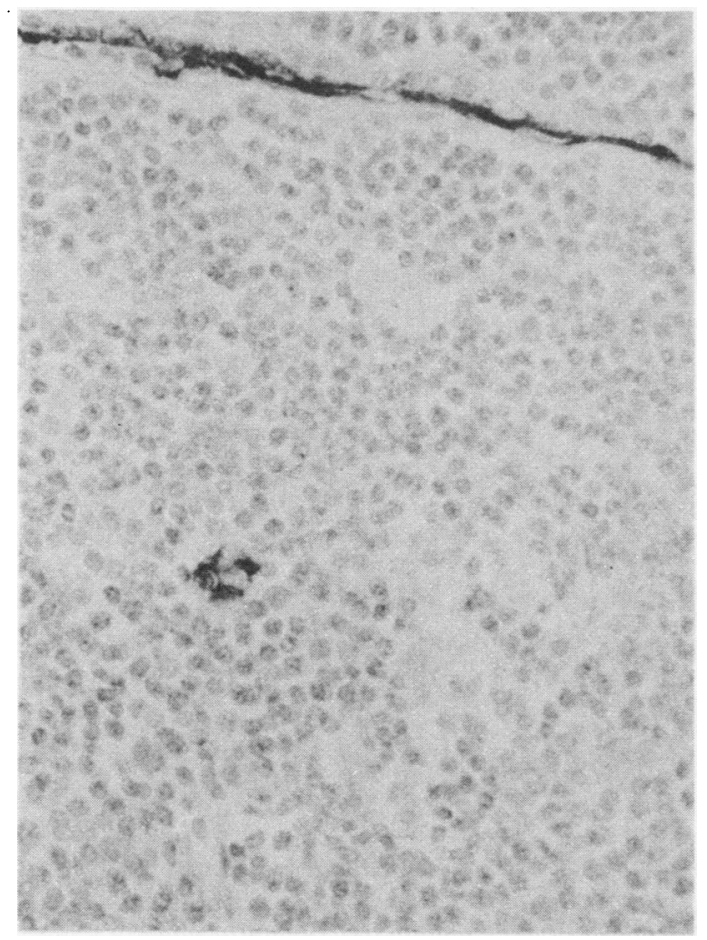

Fig. 6 Specimen of lymphocyte predominant Hodgkin's disease showing typically sparse small blood vessels. PAP method for F VIII R Ag; haemalum counterstain $\times 300$.

\section{Discussion}

Factor VIII-related antigen (F VIII $\mathrm{R} \mathrm{Ag}$ ) has recently been used as a convenient "marker" for endothelial cells and consequently of vascular structures. Factor VIII itself is composed of three functional components, namely, a precipitating antigen, von Willebrand factor and a clot-promoting molecule (F VIII C). ${ }^{3}{ }^{14}{ }^{15}$ The foremost of these, the precipitating antigen, F VIII R Ag, is synthesised by endothelial cells. ${ }^{1-3}{ }^{5} \mathrm{~F}$ VIII $\mathrm{R} \mathrm{Ag}$ is also observed in platelets and megakaryocytes, as shown by means of immunoelectron microscopy. ${ }^{16}$ Subsequently, Mukai et al ${ }^{6}$ demonstrated F VIII R Ag in endothelial cells in paraffin sections, using the unlabelled antibody peroxidase-antiperoxidase (PAP) method. This technique has also been applied to angiosarcomas ${ }^{8}$ and to a juxtaglomerular tumour. ${ }^{17} \mathrm{~A}$ series of cutaneous lesions of vascular origin were studied by Burgdorf $e t$ $a l^{18}$ using F VIII $\mathrm{R} \mathrm{Ag}$ localisation to demonstrate endothelial cells.

There have, however, been relatively few accounts of F VIII $\mathrm{R} \mathrm{Ag}$ identification in lymphoid tissues. Wright et $a^{19}$ demonstrated the antigen in some of the atypical endothelial cells of angiolymphoid hyper-

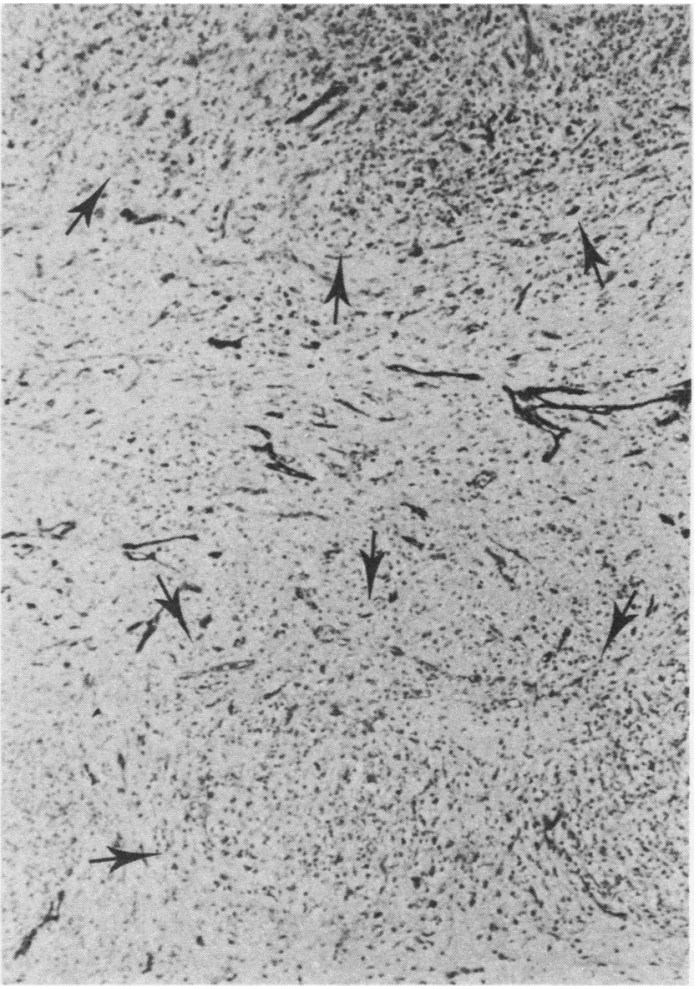

Fig. 7 Specimen of nodular sclerosing Hodgkin's disease showing many, complex F VIII R Ag-positive vessels between two cellular nodules, whose outlines are indicated by arrows. PAP method for F VIII R Ag; haemalum counterstain $\times 120$.

plasia with eosinophilia (which also contained bizarre Weibel-Palade bodies). In a study of angiofollicular lymph node hyperplasia (Castleman's disease), Jones et $a l^{20}$ described F VIII $\mathrm{R} \mathrm{Ag}$ activity (by the PAP method) in the component blood vessels of this condition in a series of four cases. High endothelial vessels were strongly positive whilst the larger vessels entering follicle centres stained only weakly.

The present study has demonstrated a striking difference between nodular sclerosing Hodgkin's disease and the other Rye subtypes, by virtue of extreme vascularity aroud cellular nodules, within the periphery of nodules and the relatively acellular intervening fibrous trabeculae. Similar vascularity is evident around follicles in reactive follicular hyperplasia but in lymphocyte predominant, mixed cellularity and lymphocyte depleted Hodgkin's disease vessels staining for F VIII $\mathbf{R ~ A g}$ are relatively scanty: This may, in part, reflect a genuine lack of blood vessels in these subtypes or may be related to the presence of such structures which do not stain for 


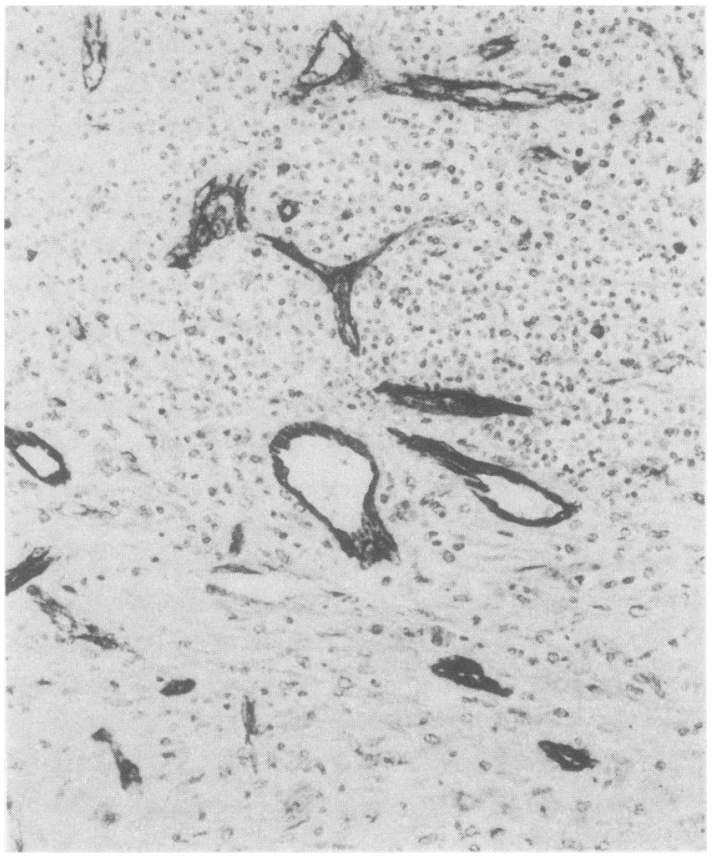

Fig. 8 Edge of a cellular nodule in nodular sclerosing Hodgkin's disease showing typically numerous and branching F VIII R Ag-positive vessels within and around the periphery. PAP method for F VIII R Ag; haemalum counterstain $\times 250$.

this antigen. Nonetheless, the finding has been a constant one in the 45 nodes examined.

The significance of the findings is uncertain; however, the presence of striking F VIII $\mathrm{R} \mathrm{Ag-}$ positive vascularity even in the cellular variant of nodular sclerosis, where little fibrosis is evident, could suggest that the vascular reaction in some way induces collagen synthesis in the stroma. Clearly, this requires further investigation. High endothelial vessels are regarded as a principal route for the ingress of lymphocytes into lymphoid tissue ${ }^{21}$ and their frequency in nodular sclerosing Hodgkin's disease is of interest. It could be hypothesised that the fibrosis characteristic of this subtype results from tissue damage caused, by some means, from lymphocyte/ Reed-Sternberg cell interaction ${ }^{22}$ or from a reaction between lymphocytes and "Hodgkin cells". It has previously been proposed that a cell-mediated attack on Hodgkin cells could be of quintessential importance in Hodgkin's disease. ${ }^{23}$

Unusual vascular structures in Hodgkin's disease have previously been noted by Söderström, ${ }^{10}$ using conventional thin-section histological techniques. High endothelial vessels were observed in large numbers in all nine specimens of Hodgkin's diseas

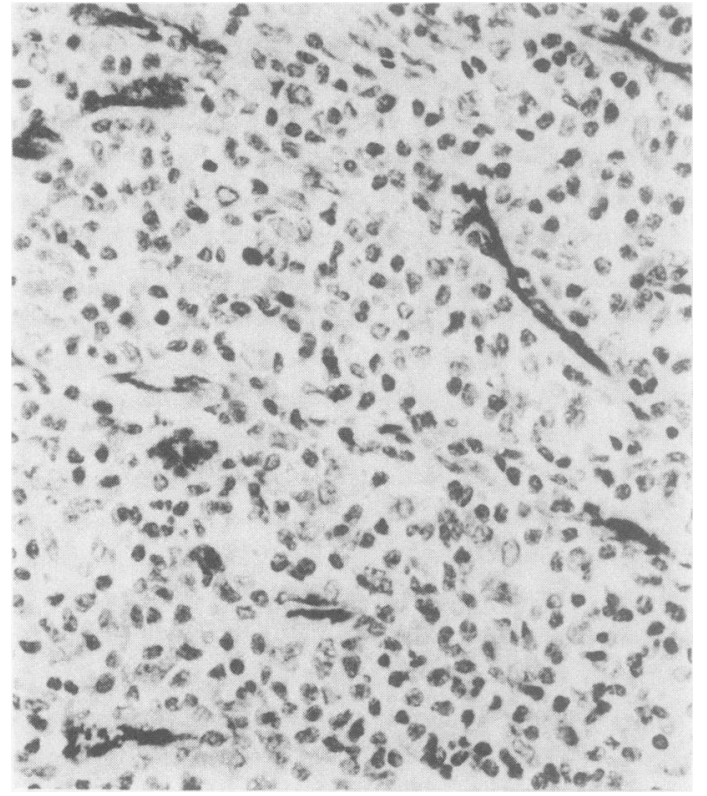

Fig. 9 Typical field from a specimen of the cellular variant of nodular sclerosing Hodgkin's disease. Many F VIII R Ag-positive blood vessels are present, in contrast to lymphocyte predominant, mixed cellularity and lymphocytic depleted specimens. PAP method for F VIII R Ag; haemalum counterstain $\times 300$.

examined (lymphocyte predominant, nodular sclerosis and mixed cellularity subtypes), in contrast to five of six nodes infiltrated by chronic lymphocytic leukaemia, where such high endothelial vessels were absent. In four specimens of "lymphosarcoma" and "reticulum cell sarcoma" (sic) high endothelial vessels were again absent. The author did not note differences in frequency or arrangement of these (or other) blood vessels, however, in different subtypes of Hodgkin's disease. It was observed that the high endothelial vessels in Hodgkin's disease (especially the nodular sclerosis variety) lacked the lymphocytic sheath usually seen around such structures.

In an early enzyme histochemical study of lymphoid tissues, ${ }^{11}$ peculiar alkaline phosphatasepositive structures were noted around nodules in Hodgkin's disease specimens. These possessed a complex network structure. This finding was supported in a more recent study by Crocker, ${ }^{12}$ who again showed striking alkaline phosphatase activity at the periphery of cellular nodules in Hodgkin's disease; similarly high vascularity was also observed in reactive follicular hyperplasia. Unfortunately, alkaline phosphatase methodology suffers from two disadvantages in this context. Firstly, the techniques 
require the use of frozen sections, thus rendering careful morphological study impossible. Secondly, certain lymphocytes, such as those in follicle "mantle zones" and those comprising certain lymphomas may possess surface alkaline phosphatase activity, thus making interpretation of vascular structures difficult. ${ }^{12}{ }^{24} 25$ In addition, high endothelial cells are probably usually negative for alkaline phosphatase ${ }^{26}$ Thus, localisation of F VIII R Ag in endothelial cells in paraffin-processed sections appears to be a superior method for the demonstration of vascular structures. The staining appears fairly specific, as the sinuses of lymph nodes (as in the reactive follicular hyperplasia specimens described) are consistently negative for F VIII $\mathrm{R} \mathrm{Ag}$; this is also the case for alkaline phosphatase, which is absent from these structures. ${ }^{127}$ However, the demonstration of F VIII $\mathrm{R} \mathrm{Ag}$ in mast cells was unexpected, although the phenomenon has previously been described by Kindblom $^{28}$ who suggested that it may be of functional importance in relation to haemostasis. The significance of occasional weakly-positive plasma cells is uncertain but has also been noted previously. ${ }^{20}$ In the current study, the strong staining of mast cells and weak, irregular staining of plasma cells were both abolished by pre-adsorption of the antiserum to $F$ VIII R Ag by the antigen itself. The morphological appearance of these cell types and of endothelial cells/blood vessels enabled their distinction to be readily made.

The localisation of F VIII R Ag-positive mast cells within and adjacent to the marginal and medullary sinuses in reactive follicular hyperplasia was a constant finding. These cells may be in transit further into the nodal parenchyma, having entered the peripheral sinus via afferent lymphatics. Lennert ${ }^{29}$ regards mast cells as arguably stationary elements of the normal node, however. Using toluidine blue at pH 3 as a stain, Thoresen and Hartveit ${ }^{30}$ showed numerous mast cells in the sinuses of lymph nodes draining breast carcinomas and have discussed the possible role of these cells in relation to tumour metastasis.

The authors are grateful to Miss E White for secretarial assistance.

\section{References}

${ }^{1}$ Bloom AL, Giddings, JC, Wilks CJ. Factor VIII on the vascular intima: Possible importance in haemostasis and thrombosis. Nature (New Biol) 1973;241:217-9.

${ }^{2}$ Hoyer, LW, De Los Santos RP, Hoyer JR. Antihaemophilic factor antigen: Localisation in endothelial cells by immunofluorescent microscopy. J Clin Invest 1973;52:2737-44.

3 Jaffe EA. Synthesis of factor VIII antigen by cultured human endothelial cells. Ann N Y Acad Sci 1973;240:62-9.

4 Jaffe EA. Endothelial cells and the biology of factor VIII. $N$ Engl J Med 1977;296:377-83.

5 Jaffe EA, Hoyer LW, Nachman RL. Synthesis of antihaemophilic factor antigen by cultured human endothelial cells. J Clin Invest 1973;52:2757-64.

${ }^{6}$ Mukai K, Rosai J, Burgdorf WHC. Localisation of factor VIIIrelated antigen in vascular endothelial cells using an immunoperoxidase method. Am J Surg Pathol 1980;4:273-6.

${ }^{7}$ McComb RD, Jones TR, Pizzo SV, Bigner DD. Specificity and sensitivity of immunohistochemical detection of factor VIII/von Willebrand factor antigen in formalin-fixed paraffin-embedded tissue. J Histochem Cytochem 1982;30:371-7.

${ }^{8}$ Guarda LA, Ordonez NG, Smith JL, Hanssen G. Immunoperoxidase localisation of factor VIII in angiosarcomas. Arch Pathol Lab Med 1982;106:515-6.

9 Jeanneau Christine, Sultan Yvette. Localization of Factor VIII/ von Willebrand Factor Antigen by immunoelectron microscopy in human endothelial cells using Fab fragments coupled to peroxidase. J Histochem Cytochem 1982;30:1091-6.

${ }^{10}$ Söderström N. The specific post-capillary venules of lymphoglandular tissue in Hodgkin's disease. In: Musshoff K, ed. Recent results in cancer research Vol 46. Heidelberg: SpringerVerlag, 1974:45.

"Nanba K, Itagaki T, Jijima S. Enzyme histochemical investigations of human malignant lymphomas. Beitr Path Bd $1975 ; 154: 233-42$.

${ }^{12}$ Crocker J. The enzyme histochemistry of lymphomas. University of Cambridge: MD thesis, 1983.

${ }^{13}$ Curran RC, Gregory J. The unmasking of antigens in paraffin sections of tissue by trypsin. Experientia 1979;33:1400-1.

${ }^{14}$ McKee PA, Anderson JC, Switzer ME. Molecular structural studies of human factor VIII. Ann N Y Acad Sci 1975;240:8-33.

${ }^{15}$ Ratnoff OD. Antihaemophilic factor (Factor VIII). Ann Intern Med 1978;88:403-9.

${ }^{16}$ Piovella F, Nalli G, Malamani GD, Majolino I, Frassoni F, Sitar GM, Ruggeri A, Dell Orbo C, Ascari E. The ultrastructural localisation of factor VIII-antigen in human platelets, megakaryocytes and endothelial cells utilizing a ferritin labelled antibody. Br J Haematol 1978;39:209-13.

${ }^{17}$ Sanfilippo F, Pizzo SV, Croker BP. Immunohistochemical studies of cell differentiation in a juxtaglomerular tumour. Arch Pathol Lab Med 1982;106:604-7.

${ }^{18}$ Burgdorf WHC, Mukai K, Rosai J. Immunohistochemical identification of factor VIII-related antigen in endothelial cells of cutaneous lesions of alleged vascular nature. Am J Clin Pathol 1981;75:167-71.

${ }^{19}$ Wright DH, Padley NR, Judd MA. Angiolymphoid hyperplasia with eosinophilia simulating lymphadenopathy. Histopathology 1981;5:127-40.

20 Jones EL, Crocker J, Gregory J, Guibarra M, Curran RC. Angiofollicular lymph node hyperplasia (Castleman's disease): an immunohistochemical and enzyme-histochemical study of the hyaline-vascular form of lesion.J Pathol 1983; submitted for publication.

${ }^{21}$ Curran RC, Gregory J, Jones EL. The distribution of immunoglobulin and other plasma proteins in human reactive lymph nodes. J Pathol 1982;136:307-32.

${ }^{22}$ Payne SV, Newell DG, Jones DB, Wright DH. The Reed Sternberg cell/lymphocyte interaction. Ultrastructure and characteristics of binding. Am J Pathol 1980;100:7-24.

${ }^{23}$ Order SE, Hellman S. Pathogenesis of Hodgkin's disease. Lancet 1972;i:571-3.

${ }^{24}$ Poppema S, Elema JD, Halie MR. Alkaline phosphatase positive lymphomas and lymphocytes. Adv Exp Med Biol 1978;114: 575-7.

${ }^{25}$ Nanba K, Jaffe ES, Braylan RC, Soban EJ, Berard CW. Alkaline phosphatase-positive malignant lymphoma. A subtype of B-cell lymphomas. Am J Clin Pathol 1977;68:535-42.

${ }^{26}$ Freemont AJ, Jones CJP. Light microscopic, histochemical and 
ultrastructural studies of human lymph node paracortical venules. J Anat 1983;136:349-62.

${ }^{27}$ Crocker J, Williams Mary. An enzyme histochemical study of the sinuses of reactive lymph nodes. J Pathol 1983; in press.

${ }^{28}$ Kindblom LG. Factor VIII related antigen and mast cells. Acta Pathol Microbiol Immunol Scand 1982;90:437-9.

${ }^{29}$ Lennert K. Malignant lymphomas other than Hodgkin's disease. Heidelberg: Springer-Verlag, 1978:70.
${ }^{30}$ Thoresen S, Hartveit F. Mast cells in the nodal sinus reaction in breast cancer. Histopathology 1982;6:765-9.

Requests for reprints to: Dr J Crocker, Department of Histopathology, East Birmingham Hospital, Bordesley Green East, Birmingham B9 5ST, England. 